\title{
CONFIRMATION THROUGH CONFLICT? SOME QUESTIONS FOR THE DIALOGUE OF TOUCHSTONES
}

\author{
Paul F. Knitter \\ Xavier University
}

My first reading of Maurice Friedman's essay produced much the same effects that are had-today, alas, so seldom-from a good sermon. I was downright inspired and enlivened with new insights and new hopes concerning the contemporary encounter of religions. With his image of touchstones, Friedman avoids academic annotated analysis and provides creative, practical theology. Though he does not indicate it through notes or references, he is very well acquainted with the literature and central issues in the contemporary discussion on "the many religions"- how to understand them and how to lead them to a more authentic and effective dialogue.

The particular power of Friedman's proposal is the way it creatively and suggestively searches for a middle path between absolutism and relativism. He realizes that these two "isms" are pitfalls for both conservative exclusivists and liberal pluralists. Though certainly of a more liberal bent himself, Friedman is well aware that typical "liberal" appeals for greater openness, tolerance, and equality among religions are often only steps away from the slippery slopes of indifference and relativism. So with guidance from his "touchstones" of truth, he affirms both radical pluralism and at the same time radical relatedness.

And he balances both. On the one hand, he chides pluralists (like me!) and urges them actually to recognize and accept what they are advocating - that religious pluralism is real and will not go way, that there will always be many, and especially that one can never find the ultimate system that will finally and neatly interrelate the many. One can never make a "system" out of pluralism (not even a "theocentric" system!). As soon as we have discovered-or imposed-a unifying pattern of interrelatedness, we have, actually, destroyed pluralism. And yet, on the other hand, Friedman does not fall into the incommensurability gap; religions are not so different that they cannot talk to each other. The touchstones touch, and must touch, each other. Within the diversity, therefore, there is a potential (not given) relatedness-the possibility and the necessity of talking to each other. As he puts it, we are "really different and yet really together." And for those of us who are concerned about losing the uniqueness of our own religion or savior, Friedman tells us that we can be both "faithful and diverse"-faithful to our uniqueness, yet embracing and learning from the uniqueness of others. With such images and hopes, the interreligious dialogue can bound forward. 
Yet as I bounded with him, I felt myself held back by a nagging question. If Friedman can help me clarify this question, I will be able to follow him all the more enthusiastically. Is his vision of dialogue perhaps too irenic or optimistic? This question tugged every time he repeated his recurring theme of "a mutually confirming dialogue of touchstones." It seems that for Friedman the encounter of religious believers will be, if not always at least basically, confirming. Now I realize that he does not mean by this a pacific blending of viewpoints. Yet in only one paragraph does he explicitly warn against passive acceptance and tolerance, recognizing that "sometimes the strongest opposition" is necessary. I suggest that Friedman needs to say more about the possibility of a real clash of touchstones, of mutual incompatibilities, of possible ruptures in the dialogue. What happens when "in listening to the other we" do not "hear something genuine to which we can respond"? What do I do when the dialogue with another believer does not "point me toward greater openness"? How does Friedman account for such possibilities?

In order to strengthen and clarify his image of touchstones, I think Friedman needs to recognize more explicitly that there can be "touchstones of unreality," that religions can provide "detours from reality." The history of religions, as well as our contemporary religious scene, seems to indicate how religions can become ideologies-means of selfaggrandizement and manipulation of others. Langdon Gilkey, an ardent advocate of interreligious dialogue, has said that in his experience of dialogue he has encountered some religious views or touchstones that he can describe as nothing else but "intolerable." Friedman, I think, has not sufficiently recognized the intolerable in religion; nor has he said enough about what we are to do when we encounter the intolerable in dialogue.

A related question: would Friedman recognize situations in which I find not that my touchstone of reality is "opened" and "enhanced" through the community of otherness but, rather, placed in question-in radical question? Might I ever be faced with the possibility or even necessity of abandoning my touchstone for another? Indeed, in affirming my touchstone and in trying to relate it to the past and to others, do I not also have to stand ready, at least theoretically or methodologically, to abandon it?

This raises another related and more sticky question: what are the criteria by which we can judge whether the dialogue of touchstones is mutually contradictory rather than mutually confirming-whether another religious touchstone might be intolerable or whether it might be calling me to revise or abandon my own? In judging another touchstone as intolerable and in taking "strong opposition" to it, am I not imposing my touchstone on it? Can Friedman offer us criteria for the truth or 
validity of touchstones that are more precise and practical than the ones he lists at the end of his essay? Or, in making this request, am I falling prey to the enticements of "foundationalism" or "objectivism" and hankering after a criteriological Archimedian point outside the dialogue?

Perhaps Friedman's response to these questions will be as simple as it is engaging: the reason why he finds, or hopes to find, the dialogue of touchstones much more confirming than contradictory, the reason why he believes that even our "strongest opposition" to another touchstone can turn out to be "confirming," is his faith in what he calls "the totally nonobjectifiable myth of the Community of Otherness." Friedman has accepted-or been possessed by-this myth; it is a matter of faith. Panikkar would call it a "cosmic trust" that the incorrigible diversity of religious touchstones is ultimately more unitive than divisive, that despite our differences and even contradictions, it is possible and necessary and beneficial to keep on talking and sharing.

Together with many others, I too share-or want to share-this myth of "the Community of Otherness." Friedman has helped me reaffirm it. I suggest that his help will be all the more valuable if he would follow the suggestions of liberation theologians and show more clearly that and how our Community of Otherness can grow not only through mutual confirmation but also through mutual confrontation, even conflict. 